\title{
Neither Bad Apple nor Bad Barrel - How the Societal Context Impacts Unethical Behavior in Organizations
}

\author{
Michael Gonin \\ University of Zurich (Research Priority Program Ethics) \\ University of Lausanne \\ (Faculty of Business and Economics and Faculty of Social and Political Sciences) \\ Internef Building \\ CH-1015 Lausanne \\ Switzerland \\ Tel.: +41 (0) 216923679 Fax: +41 (0) 216923305 \\ michael.gonin@unil.ch
}

\section{Guido Palazzo}

University of Lausanne (Faculty of Business and Economics)

Internef Building

CH-1015 Lausanne

Switzerland
Tel.: +41 (0) 216923373 Fax: +41 (0) 216923305
guido.palazzo@unil.ch

\section{Ulrich Hoffrage}

University of Lausanne (Faculty of Business and Economics)

Internef Building

CH-1015 Lausanne

Switzerland

$$
\begin{gathered}
\text { Tel.: +41 (0) } 216923490 \text { Fax: +41 (0) } 216923495 \\
\text { ulrich.hoffrage@ unil.ch }
\end{gathered}
$$

Pre-peer reviewed version of the article published in

Business Ethics: A European Review Vol. 21(1)

DOI: $10.1111 / \mathrm{j} .1467-8608.2011 .01643 . x$ 


\title{
Neither Bad Apple nor Bad Barrel - How the Societal Context Impacts Unethical Behavior in Organizations
}

\begin{abstract}
Every time another corporate scandal captures media headlines, the 'bad apple vs. bad barrel' discussion starts anew. Yet this debate overlooks the influence of the broader societal context on organizational behavior. In this article, we argue that misbehaviors of organizations (the 'barrels') and their members (the 'apples') cannot be addressed properly without a clear understanding of their broader context (the 'larder').

Whereas previously, a strong societal framework dampened the practical application of the Homo economicus concept (business actors as perfectly rational and egocentric utilitymaximizing agents without any moral concern), specialization, individualization, and globalization led to a business world disembedded from broader societal norms. This emancipated business world promotes a literal interpretation of Homo economicus among business organizations and their members.
\end{abstract}

Consequently, we argue that the first step toward 'healthier' apples and barrels is to sanitize the larder, that is, adapt the framework in which organizations and their members evolve. 


\section{Introduction}

Every time the economy is rocked by another scandal of corporate misbehavior, the well-known 'bad apple vs. bad barrel' discussion captures media headlines. The recent scandals of some financial institutions have been no different. Yet this discussion of individuals versus organizations as drivers of bad business practices ignores the impact that the broader societal context has on both individual actors and organizations. Whether apples rot not only depends on the apples themselves and the barrels, but also on the larder - even the best apples contained in the best barrels might decay if the larder is warm and full of moisture.

In this article, we argue that the dark side of organizations (the 'barrels') and their members (the 'apples') cannot be addressed properly without a clear understanding of the context in which they are located (the 'larder'). As we argue below, the institutionalized view of the roles and responsibilities of individual and organizational actors has an impact on how they behave. Business decisions are not made in a vacuum, but are embedded in normative forces that are stronger than the organizations themselves. For decades, management theory and practice have built on various normative concepts developed in economics (Ferraro et al. 2005, Ghoshal Moran 1996, Khurana 2007), including the Homo economicus (HE) concept which is the idea that individuals are fully rational and merely egocentric utility maximizers. Yet the interpretation and practical application of those concepts have dramatically changed recently. Early authors acknowledged that a stable societal context exists that sets implicit boundaries on self-interest (Friedman 2002 [1970], Pareto 1971 [1906]: 11, see Heath 2009). Granovetter emphasizes that self-interest is beneficial for economic growth only if the HE remains civilized, and argues that originally, "the pursuit of economic self-interest was typically not an uncontrollable 'passion' but a civilized, gentle activity" (1985: 488). In his 
view, the HE always remained embedded in a broader context, "constrained by ongoing social relations", and therefore construing the HE "as independent is a grievous misunderstanding" (1985: 482).

We posit that important changes in the broader societal context took place in the past decades that weakened the constraining power of societal norms over the HE thereby promoting uncivilized behavior in organizations. We do not intend to deliver another contribution to the old discussion of whether or not the HE is a legitimate approach to conceptualize behavior within organizations. There is a well established discussion on the anthropological (e.g., Fontrodona Sison 2006, Manstetten 2000, Sassower 2010) and ethical (e.g., Etzioni 1989, Feldman 1996) limits of the concept. Instead, we focus on Granovetter's idea of embeddedness and critically analyze whether there is still such a civilizing effect of societal institutions on the HE. Referring to institutional theory, we posit that the broader context plays an important role for the interpretation and application of behavioral norms. We agree with Granovetter that, historically, the context in which the HE was embedded might have prevented a radical interpretation of the concept within organizations. However, as we will argue, the embeddedness of economic life observed by Granovetter (1985), but also by Popper (2003 [1945]) or even Friedman (2002 [1970]) can no longer be taken for granted. Rather, the economic system with its business organizations is greatly "disembedded", that is, following Polanyi's (1957: 68) definition of the term, it stays "apart from the rest of society" and is "governed by laws of its own".

Three recently intensified processes have weakened the framing power of the context over business organizations. First, specialization has allowed for a systemic disembedding of the business organizations and their members from their broader societal context, allowing for the emancipation of organizational members from normative claims beyond the limited scope of economic duties. Second, individualization has fragmented the normative context of 
business actors, further weakening the impact of moral custom on HE's decisions. Third, globalization is legally disembedding business actors from the regulatory framework of society. This threefold disembedding process has dramatically changed the normative context of organizations and their members.

This paper is structured as follows: We start with a critical discussion of the HE rationality. We then outline the concept of institutional embeddedness and its relevance for the interpretation of the HE concept within organizations. Afterwards, we describe the driving forces of the threefold disembedding process: specialization, individualization, and globalization - and the consequences of this process on the dark side of organizations. We also explain why, from an institutional theory perspective, the ethically enlarged concepts of rationality such as the Kantian or the Aristotelian ones do not suffice to cope with those dark sides. The paper concludes with implications for future research and managerial practice regarding dark sides of organizations.

\section{Homo Economicus as a mainstream behavioral concept}

According to the HE concept, individuals within the economic system can be viewed as rational, informed, egocentric, utility-maximizing, and autonomous agents. Such actors are assumed to act coherently, based on the available information, to maximize their own interests. Very often, this concept is even extended to business organizations. The latter can be conceived of as abstract legal persons who in their structures and processes show similar characteristics to the ones of individual economic agents. The normative justification of the HE concept rests on the assumption that if everybody cares only for him/herself, over time everybody will benefit. Adam Smith's assertion that "it is not from the benevolence of the butcher, the brewer, or the baker, that we expect our dinner, but from regard to their own interest" (1981 [1776]: 26-27) or Friedman's famous article title "The social responsibility of 
business is to increase its profits" (2002 [1970]) are illustrations of such strongly self-oriented reasoning of individuals and corporations alike.

Even though early authors never conceived the HE as an empirically valid construct, Friedman (1953) considered it sufficient to conceptualize economic actors as if they were HE, and much current research points towards a questionable empirical validity of the model (see e.g., Elster 2009, Herrnstein 1993: 139, Hertwig Herzog 2009, Marwell Ames 1981). This model remains the dominant idea on which economics and management rely in the conceptualization of 'rational' human behavior in organizations. Refinements of the concept have been proposed by various authors (e.g., Akerlof Schiller 2009, Fehr Gächter 2002, Frey Stutzer 2002, Gilovitch et al. 2002, Kahneman et al. 1982), but are not yet sufficiently integrated into managerial theory. The latter is still dominated by the simplistic and vulgarized concept of the HE as the characterization of the individual (Friedman 2002 [1970], Homans 1958, Jensen Meckling 1976, see critically Khurana 2007). Transaction-cost theory (Williamson 1975) and principal-agent theory (Rees 1985a, b), for instance, both refer, more or less explicitly, to the original, narrowly defined HE concept and have tremendously influenced how managers see their tasks and how organizations are structured and function (Ferraro et al. 2005, Ghoshal Moran 1996, Khurana 2007).

Heath's (2009) analysis of the principal-agent theory shows however that the problem is not the theory itself, but rather its strong relation to the HE concept combined with a neglect of broader societal norms. Most often, the principal-agent theory builds on the HE concept and so proposes a strongly self-centered conception of the individual actor within an organization - the 'bad apple' in the introductory metaphor - to be kept in check by the sanctions and incentives built into the design of the barrel. Yet this conception of individual actors does not necessarily reflect the human nature of organization members. As mentioned above, the HE concept was originally intended to be a theoretical construct, and not to be a 
discussion of the real nature of the apple. Its primary utility was the development of coherent mathematical models in economics (Friedman 1953, Khurana 2007). However, while it seems clear that the HE does not describe the potentialities of human behavior, it might become so powerful as a conceptual metaphor that it influences what individuals do when in a managerial role. Since the Reagan / Thatcher era of the 1980's, and especially after the fall of the Berlin Wall, various factors have allowed the HE concept to become "performative" (Callon 2007) and to gain increasing normative authority over the daily practice in organizations (Bohle Greskovits 2006, Shields 2007). In the next section, we will argue that the main causes are neither decays in the apple, nor flaws in the barrel, but rather in the 'larder', that is, the broader societal context in which organizations are integrated. Specialization, individualization, and globalization have weakened the specific societal framework of the $20^{\text {th }}$ century which was characterized by rather homogeneous traditions and values as well as a strong democratic nation state capable of preventing a radical application of the HE concept in practice (Barber 2000, Gonin 2007a).

\section{The concept of institutional embeddedness}

According to institutional theory, individual actors are embedded in institutions. Institutions are conceptualized as "shared definitions or meanings" (Tolbert Zucker 1996: 180) and sets of taken-for-granted behavioral norms justified by their relationship to some formal, non-personal structure (Berger Luckmann 1967). These standardized perceptions and routine behaviors are adopted in an unconscious manner by most members of a community in order to minimize their decision-making efforts (Tolbert Zucker 1996, see also Betsch Haberstroh 2005, DiMaggio Powell 1983, Meyer Rowan 1977). They can be considered as the larder in which the apple barrels are located. As such, they influence the way organizations and individual actors within organizations perceive the world, their role, the 
salience of issues and the persuasiveness of solutions (Thornton 2002). Moreover, the institutional context is the reference point for the evaluation of the legitimacy of organizations: Their goals, values and behaviors are evaluated in the light of the existing institutional order (Ashforth Gibbs 1990, Oliver 1991, Suchman 1995).

Institutional theory supposes that many decisions are copies of the behavior or of the values adopted by other similar actors (Aldrich Fiol 1994), even though such copies might be strategically irrational (DiMaggio Powell 1983) or inefficient (Meyer Rowan 1977). This copy process enhances the institutionalization of a specific behavior or norm, and the more a behavior or a norm is institutionalized, the more likely it is to be considered as the new standard to be followed, and so adopted by other actors in the field (Barley Tolbert 1997, Zucker 1987).

The institutionalization of a standard or behavior is further increased through the development of socially accepted justifications (i.e., legitimacy) (Berger Luckmann 1967). As science represents an important source of normative authority in our Western societies (Berger Luckmann 1967, Popper 1990 [1934]), scientific concepts of the world play an important role in increasing or decreasing the legitimacy of a specific institution and consequently its normative influence (Berger Luckmann 1967, Khurana 2007). For instance, various authors discuss the importance of economic theory in strengthening the normative influence that the HE concept has on corporate practice (e.g., Khurana 2007, Mintzberg 2004). Empirical work confirms the contribution of theory to the institutionalization process. Several studies involving students have shown that economic theories taught in the classroom influence business students' behavior toward stronger egocentrism in comparison to students of other disciplines (see Büchner et al. 2007, Frank et al. 1993, Marwell Ames 1981, Selten Ockenfels 1998). McCabe, Butterfield, and Trevino (2006) further observed that business 
students not only cheat more than others, but also legitimize their cheating by the fact that they see other students also cheating.

In summary, institutional theory highlights the importance of the context for the way individual actors within organizations interpret and apply models perceived around them. This implies, for the business context, that the way the HE concept is understood and applied in practice is never 'context-free'. It is shaped through the interplay of various explicit and implicit worldviews and values present in the broader society to which the concept is connected (DiMaggio Powell 1983, Giovanola 2009).

In the next section, we first discuss the former embeddedness of organizations in a broader societal framework that kept their actors implicitly submitted to societal values and guaranteed the legitimacy of a HE-based economic thinking. We then discuss the threefold disembedding process through which business organizations and their actors gained autonomy from the implicit influence of the broader society.

\section{The Disembedded Homo Economicus}

\section{Former implicit links between business and societal}

\section{framework}

Several authors have pointed out that today's understanding of the $\mathrm{HE}$ as an undersocialized and atomized agent clashes with the conception of its originators. As we have argued, the organizational barrel was always related to a specific larder. Early economists implicitly or explicitly conceptualized the HE within a strong institutional context. This context contained numerous behavioral norms, routines, and traditions that shaped organizations and their individual members. In the American business context this can be illustrated by the influence of the Dissenting Protestantism tradition. Here, the public 
demonstration of moral decency has been a core element of business culture, thereby linking activities within the business organizations with moral expectations from outside of the organization. For instance, Max Weber observed during his journey through the United States that having moral values and being part of a religious community was of utmost importance for business transactions. He illustrates this thesis with a vignette, quoting a traveling salesman with whom he had a conversation about American religion. When Weber (1976 [1906]: 303) commented on the strong church-mindedness in the USA, the traveling salesman answered:

"Sir, for my part everybody may believe or not believe as he pleases; but if I saw a farmer or a businessman not belonging to any church at all, I wouldn't trust him with fifty cents. Why pay me, if he doesn't believe in anything?"

This embeddedness of the HE was still relevant during the period in which the HE concept developed its strongest impact in the form of neoliberal theory, namely in the middle of the $20^{\text {th }}$ century industrial society. A more or less stable and homogeneous set of values, along with the regulations of comparably powerful national governments, were able to set the boundaries preventing overstretched interpretations of the HE concept (Palazzo Scherer 2006). Of course, this does not mean that there was no bad apple, but the historical evolution of civilized behavior (Elias 1994 [1939]) set clear boundaries to unbridled egoism, both in market transactions and within business organizations.

This homogeneous overarching societal framework contained the normative interpretation of the HE concept, implicitly softening its impact on business organizations and their members (Chewning 1984). Through institutional copy processes (Aldrich Fiol 1994, DiMaggio Powell 1983, Zucker 1987), many pro-social values were implicitly applied within most companies (see the study of Galaskiewicz 1991), as they were considered to be 
unquestionable standards of civilized interaction. Critiques of methods which can currently be observed in many business organizations often use metaphors that relate to the notion of business actors embedded in a broader framework. For instance, Barber (2000: 275) suggests that "we have removed capitalism from the institutional 'box' that has (quite literally) domesticated it and given its sometimes harsh practices a human face." Others describe corporations as barbarians at the gate (Burrough Helyar 2004), cannibals with forks (Elkington 1998), or robber barons (Burbach 2001).

In summary, from the beginning of the industrial era until the 1980's, business organizations and their members were embedded in a civilizing societal context that strongly influenced - but was also influenced by - them (Granovetter 1985). The latter was legitimized only because concepts such as that of the HE were interpreted and applied in a manner compatible with the broader societal framework.

\section{The disembedding process}

In the past decades, the idea of a culturally civilized HE has been increasingly challenged through an ever-accelerating process of institutional erosion. The ongoing processes of specialization, individualization, and globalization have greatly weakened the traditional societal framework, leaving today's societies and actors within societies in an unprecedented situation. Of course, these processes have greatly contributed to technical and economic progress as well as to the high level of personal freedom that characterize today's Western societies. While discussing how the interplay of specialization, individualization, and globalization has affected the institutional framework, the following sections do not deny these positive developments. The aim is rather to show how these three changes also contribute to the HE's disembedding from its previous societal norms and challenge the applicability of reason-based ethical alternatives. 
Specialization: Specialization refers to the process through which actors in a network of interrelated and interdependent tasks increasingly focus on and gain expertise in specific parts. It has played an important role in the emancipation of business organizations from the broader societal context. The rise of modern society has been explained by the growing ability to handle complexity through processes of labor division (e.g., Luhmann 1982) and reliance on expert knowledge (Giddens 1991). The differentiation of systems and the impact of expert knowledge lead to a growing differentiation and specialization of the roles individuals play within the different systems. Such roles, in turn, determine group norms and prototypes as well as behavior and self-perception of individual actors (Hogg Terry 2000, Stryker 1980). The concept of prototyped role expectations or group norms "both describes and prescribes [...] what one should think and feel and how one should behave" (Hogg Terry 2001: 3). The self is understood as being "structured into relatively discrete identities" (Hogg et al. 1995: 265). For the business world, this implies that members of organizations are expected to think and behave according to their economic roles, and leave the responsibility of social and working conditions to the political actors and their processes of regulation and punishment threats - even when the latter are dysfunctional (Jensen Meckling 1976, Jensen 2002, see critically Scherer Palazzo 2007). As a result, they are disconnected from values and activities of other domains of societal life, and managerial responsibility is reduced to economic liability (Pruzan 2001). Callon (1998: 22) suggests that "the homo economicus does exist, but is not an a-historical reality; he does not describe the hidden nature of the human being". Rather, repeated teaching of this conception initiated a self-fulfilling prophecy: Many students and managers started considering this Friedmanian as-if construct as a normative model defining how one should behave in business (Ferraro et al. 2005, Ghoshal Moran 1996). 
Specialization has therefore paved the way for a systemic disembedding of business organizations and their members. The broader society let the corporations develop behavioral norms that focus on a narrow understanding of the HE and neglect non-economic dimensions.

Whereas the detachment of business actors from an overarching societal framework allowed enhanced productivity and efficiency (see Friedman 2002 [1970], Luhmann 1982, as well as Ronald Reagan's famous praise of the "magic of the market"), there is also a flip side to it. Sethi (1975) noticed for instance that deviant corporate behavior occurs more often in areas in which corporations do not feel embedded. Another dark side of role-based behavior consists of actors' tendency to develop limited views of the world. Individuals might be 'illiterate Nobel Prize Winners' (Guillebaud 2004), that is, experts in a specific field who often lack a basic understanding in other fields. Bird and Waters (1989) deplore the moral muteness of managers because many no longer master ethical language (see also Frederick Hoffman 1995). Trained to reduce management to analysis and analysis to technical and mathematical calculations, managers risk behaving with analytical immorality (Mintzberg 2004). For instance, in the Enron scandal as well as in the recent financial crisis, many managers referred to justifications following merely a HE logic in order to deny any responsibility towards stakeholders and even assert that it was the best for the welfare of society (e.g., Cohan 2009, McLean Elkind 2003, Phillips 2009). Finally, operating in a context in which people cannot see the direct consequences of their actions is one of the factors that lead to what Bandura (2002) referred to as "moral disengagement". People who focus on subdivided tasks, which seem harmless in themselves, may for instance deny responsibility for the outcome of the whole enterprise. While they are engaged in getting their specific job done, they are disengaged when it comes to applying their moral standards to evaluate the whole within which they are a part: "Where everyone is responsible no one really feels responsible" 
(Bandura 2002: 107). As a consequence, a group of specialists, each with high moral standards, may, as a collective, behave immorally.

Even though specialization promoted the emergence of actors who can be described as disembedded HE, their focus on self-interest remained, for a long time, constrained by a broader framework of legal and moral values. For instance, Friedman entitled his famous 1970 article "the social responsibility of business is to increase its profits", but acknowledged, in the same article, that economic actors follow their profit-maximizing activities within a context of basic societal rules, "both those embodied in law and those embodied in ethical custom" (2002 [1970]: 226).

However, for a few decades now, two other processes have contributed to further disembed business organizations and individuals within them from their context and free the HE from ethical and legal customs: While individualization is weakening the impact of ethical custom on business decisions, globalization is triggering a process of legal disembedding.

Individualization: Individualization can be understood as the erosion of the homogeneity of traditions, norms and values that are valid within a given society. It frees the individual from the pressure of institutional traditions and creates space for free and autonomous decision making. Actors in individualized societies tend to build their identity and decide upon their actions by making individual choices rather than by following traditions (Bell 1976: 16). This development is essential for democracies, which rely on individuals forming their own opinions and, if necessary, resisting to 'wicked' societal norms such as those of the Nazi regime (Beck Beck-Gernsheim 2002).

Yet the flip side of increased individual freedom is that the formerly homogeneous and coherent background of societal norms is being challenged by the presence of a plurality of worldviews that result from the manifold individual identity projects (Beck 1992, Giddens 1994, Habermas 1996). Members of a pluralistic society, in turn, are under constant pressure 
to make choices and to explicitly justify them. Whereas in the past one's biography was implicitly defined and justified by traditions, family customs, or social class, now individuals are forced to explicitly take a stand about their own values, worldviews, framework, and identity, and explicitly choose and combine the one(s) they want to adhere to (Ball-Rokeach Loges 1996: 281, Beck Lau 2005, Beck Beck-Gernsheim 2002). They are not only free to, but also forced to choose from various value sets that are available all around them (Gergen 2000: 218-20). This pluralization of personal worldviews makes it hard for society as a whole to preserve a strong common framework that rallies individual actions toward a coherent collective objective.

The individualization process has tremendous implications for the moral embeddedness of business organizations and their members. As illustrated above with Weber's (1976 [1906]) vignette of the travelling salesman who underlined the importance of religion for his profession, shared traditions played an important role in the morality of business organizations and their members by providing common behavioral norms. As individualization weakens the influence of an overarching set of shared values, members of business organizations lack clear overarching guidelines. They might therefore search for orientation in the normative guidelines specific to their organization - which often refer to the HE concept.

The process of individualization thus further strengthens the self-referentiality of business decisions and weakens the civilizing influence of overarching norms and values. Individuals play several different - and sometimes even conflicting - context-specific roles without integrating them into a coherent identity which is embedded in the broader societal framework (Erickson 1995). They are free to follow Friedman's (Friedman 2002 [1970]: 226) call for managers to pursue only the principal's interests, and neglect social or moral 
obligations which should be reserved for their other roles outside their business organization (see Alas et al. 2006, see critically Sennett 1998).

Globalization: Globalization can be considered as a further process that disembeds the HE from any binding contextual norms. It can be understood as an intensification of social and economic interactions across borders, accelerated by political decisions (e.g., free-trade agreements), political upheaval (e.g., fall of the iron curtain), technological advancements (communication, media, transportation), and socio-political developments (spread of knowledge, creation of new identities, etc.) (Scholte 2005, Cohen Kennedy 2000).

As new technologies allow the quick transmission of information, goods, and services around the world, corporations are able to increase their production efficiency, thereby contributing to the mass-production of products affordable to the broadest Western middle class. Moreover, new technologies allow corporations to dispatch their different activities in the countries that are most favorable to each specific task. Whereas geographically limited nation states lose regulatory power due to "the fragmentation of authority, the increasing ambiguity of borders and jurisdictions, and the blurring of the lines between the public and the private sphere" (Kobrin 2009: 350), corporations gain new liberties, and to some extent, new powers over the geographically limited nation states (Cutler 2001, Falk 2002, Kobrin 2001, Scherer et al. 2006). Consequently, firms can rely on a new instrument, 'legal arbitrage', that can be used to put pressure on governments regarding the legal framework of their activities (Chandler Mazlish 2005, Scherer et al. 2006, Young 2004). In the absence of clear regulation and law enforcement for international commerce (T. Donaldson 1996, Rawlinson 2002), they can develop their own norms of behavior and codes of conduct, without being too strongly limited by local customs (Beck 2000, Scherer et al. 2006). 
As a consequence, the $\mathrm{HE}$ is no longer civilized by a specific societal and geographical framework in the context of multinational business activities. Since political governance is limited by the borders of the nation state, there is no regulatory institution to counter-balance the growing power of multinational corporations on the global playing field (Kobrin, 2001). Outsourcing production to suppliers in countries with the lowest level of social and environmental regulation has connected Western corporations to a broad range of human rights violations and environmental abuse. Globalization has allowed for a legal disembedding of the HE.

\section{The disembedded HE}

These three processes - specialization, individualization, and globalization - have allowed for the systemic, moral, and legal disembedding of organizations and their members from the broader societal context and its civilizing norms. On the global playing field, morality and legal compliance are reduced to simple trade-offs between benefits and risks which was already suggested as a typical HE behavior decades ago (Becker 1968). Corporations operate in a context of nonexistent, weak or even contradictory legal and moral institutions. As no external framework enlightens their dark side, opportunistic HE behavior flourishes (Gond et al. 2009). Business actors might tend to evade too demanding legal requirements, especially when rules are not clearly formulated (Carroll 1987, Di Lorenzo 2007). Enron, for instance, considered accounting norms as "simply obstacles to be overcome, complex rule systems waiting to be manipulated and circumvented" (Levine 2005: 727). Avoiding rules becomes a mere economic strategy without any socio-political consideration: For an HE-spirited company that outsources production to suppliers in developing countries with weak or nonexistent governance mechanisms, human rights might be irrelevant as long as the violation of human rights neither influences the bottom line in a negative way, nor violates any local law (Kulik 2005). Similarly, environmental issues are considered by various 
corporations merely as economic constraints to be minimized, as the questionable anti-Kyoto lobbyism of some multinational corporations show (Shamir 2004, The Economist 2006).

Ultimately, the disembedding of the HE may lead to what Thomas Hobbes in his Leviathan (chapter 13) referred to as a war "of every man against every man". Even the efforts of many corporations to engage in social or environmental actions might not solve the problem of disembeddedness. Many corporations have started these activities and claim to be 'good corporate citizens' (Matten Crane 2005, Scherer Palazzo 2007). Some forms of engagement might be led by a real desire to overcome the described gap between the business system and the broader society. However, it can be assumed that many corporations follow this new trend of social integration and responsibility with a mimetic attitude (DiMaggio Powell 1983), perceiving such a move as a mere strategic action that does not go beyond a superficial greenwashing form of responsibility (Laufer 2003, Scherer Palazzo 2007). In the latter case - probably the dominant form in many business organizations (Margolis Walsh 2003) - such 'openness' to a broader social and normative reality remains an instrument used in the narrow profit maximization logic typical of the HE. It does not solve the problems emerging from institutional disembeddedness, but is rather driven by the HE logic itself. In fact, if corporate social responsibility engagement is merely instrumental, it may disappear as soon as it is no longer profitable (Weaver et al. 1999).

\section{Current Attempts to Re-embed the HE}

By discussing the broader context encompassing both the 'bad apples' and the 'bad barrels', the present analysis suggests that solutions are to be found not primarily at the level of individuals or organizations. In this section, we first argue why actions taken to increase individual and organizational ethics might not be sufficient (even though we are not 
questioning their necessity). We then conclude this article by proposing additional measures to sanitize the context in which business organizations evolve.

\section{The Insufficiency of Individual Morality}

Following criticism toward the egocentric HE and its application in management models (Bird Waters 1989, Etzioni 1989, Mintzberg et al. 2002), various management concepts that build on an enlarged model of human agency have been developed (e.g., Davis 1997, Giovanola 2009).

Interestingly, most of those alternative conceptions of economic actors do not question the idea of rationality - thereby also showing one of the core characteristics of the HE. Yet whereas economists suggest that people use their reasoning only to maximize their selfinterest, business ethicists do not restrain rationality to self-interested calculation as in the case of the HE but define it as the human ability to reason beyond self-interest (L. Donaldson Dunfee 1994). According to such authors, actors also examine, for instance, whether an intended action can be universalized (based on Kant, see Bowie 1999, Paine 1996), whether it refers to communitarian traditions and values (following the Aristotelian tradition, see e.g., Solomon 1993, Giovanola 2009), or whether it contributes to the greatest benefit of the greatest number (Mill). Approaches to business ethics that advocate win-win solutions to ethical dilemmas implicitly operate on the basis of such a Utilitarian calculation (e.g., Porter Kramer 2006). Even though they are opposed to each other on some dimensions, these ethical approaches all rely on individual reason to evaluate either the specific duty in a given decision-making situation (Kant), the consequences (Mill), or the communitarian acceptability (Aristotle) of an action.

Another commonality between such reason-based ethical approaches (L. Donaldson Dunfee 1994, Paine 1996) and the HE concept is that both neglect the influence of routines, 
habits and implicit social norms on individual decision-making and behavior (Sonenshein, 2007). In fact, the results of various studies challenge the claim that individuals first decide autonomously and then act accordingly (Asch 1951, Rest 1983, J. Weber 1991). As a consequence, institutional theory allows one to formulate a critique against authors of reasonbased ethical approaches which is similar to the one expressed against the HE: Their trust in the ability of the individual to reasonably see ethical problems and to solve them seems exaggerated in the light of empirical observations. Moreover, the complexity of $21^{\text {st }}$ century society makes it even more questionable to rely merely on the individual capacity to assess a situation and define the ethically optimal solution to follow. Specialization, individualization, and globalization lead to ethical dilemmas which are often too complex to be solved solely by the rational thinking of a single person. Whereas specialization makes it difficult for actors to understand the side effects of their actions for other parts of the society and so develop strong ethical reasoning, individualization makes it difficult to identify a common value set as standard for evaluating the legitimacy of the various alternatives. Finally, globalization often creates a geographic distance between the actors and the consequences of their actions or decisions that further blurs ethical reasoning. The issue of global warming, for instance, does not only span across many fields of expertise - it also (and especially) concerns those populations of the world who are often out of the decision makers' focus (Welzer 2008). Moreover, the plurality of worldviews and values leads to a plurality of propositions regarding how to solve the problem.

Because of their limitations and of the power of institutions, reason-based ethical approaches of management, as important as they are, might not suffice to challenge the HE thinking that prevails among members of business organizations. In consequence, and in addition to the promotion of reason-based ethics in business, it seems important to provide an 
interpretation of the individual business actor which takes into account the complexity of the $21^{\text {st }}$ century societal context.

Scholars have started to look for (re-)integrating individual behavior into new concepts of community - be it local, global, or merely virtual communities (Barber 1992, Cova Cova 2002). Various authors (e.g., Beck 2006) propose a cosmopolitan mindset with its specific worldviews to balance the mere individualistic understanding of identity. This mindset is one of the factors contributing to the development of a global framework which could re-embed the currently disembedded domains of life (Beck 2002, W. Smith 2007, see also Braithwaite Drahos 2000).

However, these efforts are not (yet) fully mature and still too disconnected from each other to provide a strong common global framework which effectively re-embeds the various domains of (social) life (May 2004). Ethical training and cosmopolitan mindsets certainly contribute to strengthening the apple's resistance to the rotting process - yet this might not suffice as globally stretched business organizations remain largely uncontrolled and unframed. In the next section, we discuss current attempts to increase the corporations' ethical behavior, and argue that those attempts might fall short as well.

\section{The Insufficiency of 'Organizational Morality'}

Specialization, individualization, and globalization have also affected the way corporations deal with moral issues. As the implicit link to a commonly shared framework is missing, corporations are often called to explicitly address ethical issues (Moon et al. 2005, Scherer et al. 2006). Corporations have answered with many organizational tools to address ethics within their structures, and compliance programs as well as code of conducts have become standard (e.g, Paine 1994, Stevens et al. 2005, Wieland 2005). Yet many authors discussing those tools admit that for various reasons, such tools often fall short of their 
objective. Among other things, they mention the fact that such documents and formal structures are often powerless as soon as overarching market forces impose a different behavior.

Furthermore, projects aimed at instilling ethics into business organizations often fail as they are confronted with a conception of the firm which also builds on the HE-spirited logic. Corporations are often conceived of as merely economically structured without social or political dimension, and managers within them tend to consider any project to enhance ethics within their organization as a mere tool to maximize profit that can and should be abandoned if no longer efficient (see Jones 1995, Gond et al. 2009, Wagner-Tsukamoto 2005). Whereas for instance the participation in global multi-stakeholder initiatives such as the Forest Stewardship Council (Bartley 2003, Pattberg 2005, see also Den Hond De Bakker 2007, Doh Guay 2006) might represent an important organizational endeavor to endorse the cosmopolitan mindset developed regarding individual actors, corporations often have difficulties in developing a new identity reflected in all dimensions of their activities. Without a paradigmatic change in the theory of the firm, projects aiming at re-embedding business organizations and their actors into a broader normative framework tend to be 'instrumentalized' by corporations as a mere strategic tool to reach economic objectives. To help organizations to enlighten their dark side and to regain legitimacy in the eyes of the broader society, not only must organizations change, but foremost the institutional framework on which organizations rely when defining their identity, objectives, and behavior norms must also change (see e.g., Palazzo Scherer 2006).

\section{Additional steps for re-embedding business into society}

As argued above, the dark side of organizations might be due to a lack of sociopolitical light shining from the broader context into business organizations. Enlightenment is 
therefore needed for business organizations and their actors to better see socio-political issues related to their work. The emergence of a broader cosmopolitan framework implies that firms can no longer be considered as mere economic entities in a (global) socio-political vacuum. Instead, they are increasingly required to explicitly address their socio-political and environmental darkness. Managers need to 'manage' the broader context which spans across nations and specialization domains. They face the challenge of explicitly integrating reflections concerning the meaning and values of business activity going beyond mere rational thinking - whether based on the HE concept or on other ethical theories. Corporate social responsibility and corporate citizenship discussions (Freeman 1994, Matten Crane 2005, Scherer Palazzo 2007) require managerial capacities which partly refer to the cosmopolitan mindset discussed above. Leaders need new tools and knowledge to build bridges toward the broader societal context, to integrate non-economic elements into decision processes, and to provide some meaning to their employees' work (Maak Pless 2006). They are forced out of a specialized profit or utility maximization task into a generalized task of integrating many different types of information and responsibilities: economic, moral, social, environmental, legal, and political.

Business scholars can and should help managers by providing new decision making models that allow for the explicit integration of social, environmental, or ethical issues. More generally, they need to redefine economic agency in broader terms than those offered by the HE concept in order to include the social and political dimensions of business actors, and so re-embed business actors in the broader societal context of the $21^{\text {st }}$ century. Anthropologists, social and political scientists, law scholars as well as business ethicists and other management scholars need to work hand in hand with economists to develop a concept of the economic actor which better integrates the complexity of today's globalized world. Only by doing so 
will they be able to develop tools for the managers to grasp this complex reality, work within it, and completely take over their societal responsibilities.

In summary we argue in this article that the way organizations and their members understand ethical issues strongly depends on the way they interpret theories that frame their fields, such as the HE concept. This interpretation, in turn, depends on the broader societal context (Ferraro et al. 2005, Ghoshal 2005, Giovanola 2009). Whereas there always were and probably always will be some bad apples and some bad barrels, constructing a sanitary larder might be the best way to prevent other apples and barrels from turning bad, too. Such potentially tremendous practical influence of the theories and their interpretation in a given context should be seen as both a warning and as an encouragement for business scholars (Gonin 2007b). It serves as a warning because it makes it clear that what is taught in academia has an impact in the real world. Scholars can no longer avoid an open and critical discussion regarding their responsibilities for the narrow conception of the HE in today's practice. At the same time, the various management scandals such as those related to the current financial and economic crisis also serve as an encouragement. Although scholars often claim to only be neutral observers of reality, the fact that such consequences may be the result of a selffulfilling prophecy suggests that an alternative model developed by them can gain, over time, practical influence and better embed the currently unbridled market actors into a broader societal worldview. Such an alternative, which scholars might develop in an attempt to garden the economic field, should set forward all possible resources of Homo sapiens to bring light into organizations; rationality as understood either by the HE concept or by alternative ethical theories is one of those resources, but is far from being the only one. 


\section{References}

Akerlof, G. A. \& R. J. Schiller. 2009. Animal Spirits: How Human Psychology Drives the Economy, and Why it Matters for Global Capitalism. Princeton: Princeton University Press.

Alas, R., J. Ennulo \& L. Türnpuu. 2006. 'Managerial values in the institutional context.' Journal of Business Ethics, 65:3, 269-78.

Aldrich, H. E. \& C. M. Fiol. 1994. 'Fools rush in? The institutional context of industry creation.' Academy of Management Review, 19:4, 645-70.

Asch, S. E. 1951. 'Effects of group pressure upon the modification and distortion of judgments.' In H. Guetzkow (Ed.) Groups, Leadership and Men. Research in Human Relations: 177-90. New York: Russell \& Russell.

Ashforth, B. E. \& B. W. Gibbs. 1990. 'The double-edge of organizational legitimation.' Organization Science, 1:2, 177-94.

Ball-Rokeach, S. \& W. E. Loges. 1996. 'Making choices: Media roles in the construction of value-choices.' In C. Seligman, J. M. Olson \& M. P. Zanna (Eds.), The Psychology of Values: 277-98. Mahwah, NJ: Lawrence Erlbaum.

Bandura, A. 2002. 'Selective moral disengagement in the exercise of moral agency.' Journal of Moral Education, 31:2, 101-19.

Barber, B. R. 1992. 'Jihad Vs. McWorld.' The Atlantic, 269:3, 53-65.

Barber, B. R. 2000. 'Can democracy survive globalization.' Government and Opposition, 35:3, 275-301.

Barley, S. R. \& P. S. Tolbert. 1997. 'Institutionalization and structuration: Studying the links between action and institution.' Organization Studies, 18:1, 73-117.

Bartley, T. 2003. 'Certifying forests and factories: States, social movements, and the rise of private regulation in the apparel and forest products fields.' Politics and Society, 31:3, 433-64.

Beck, U. 1992. Risk Society: Towards a New Modernity. London: Sage.

Beck, U. 2000. What is globalization? Cambridge: Polity Press.

Beck, U. 2002. 'The cosmopolitan society and its enemies.' Theory, Culture \& Society, 19:1-2, $17-44$.

Beck, U. 2006. Cosmopolitan Vision. Cambridge: Polity Press.

Beck, U. \& E. Beck-Gernsheim. 2002. Individualization. London: Sage.

Beck, U. \& C. Lau. 2005. 'Second modernity as a research agenda: Theoretical and empirical explorations in the 'meta-change' of modern society.' British Journal of Sociology, 56:4, 525-57.

Becker, G. S. 1968. 'Crime and punishment: An economic approach.' Journal of Political Economy, 76, 169-217.

Bell, D. 1976. The Cultural Contradictions of Capitalism. London: Heinemann.

Berger, P. \& T. Luckmann. 1967. The Social Construction of Reality. A Treatise in the Sociology of Knowledge. New York: Anchor Books. 
Betsch, T. \& S. Haberstroh. 2005. 'The Routines of Decision Making.' Mahwah, NJ: Lawrence Erlbaum.

Bird, F. B. \& J. A. Waters. 1989. 'The moral muteness of managers.' California Management Review, 32:1, 73-88.

Bohle, D. \& B. Greskovits. 2006. 'Capitalism without compromise: Strong business and weak labor in Eastern Europe's new transnational industries.' Studies in Comparative International Development, 41:1, 3-25.

Bowie, N. E. 1999. Business Ethics: A Kantian Perspective. Oxford: Blackwell.

Braithwaite, J. \& P. Drahos. 2000. Global business regulation. Cambridge: Cambridge University Press.

Büchner, S., G. Coricelli \& B. Greiner. 2007. 'Self-centered and other-regarding behavior in the solidarity game.' Journal of Economic Behavior \& Organization, 62:2, 293-303.

Burbach, R. 2001. Globalization and Postmodern Politics. From Zapistas to High-Tech Robber Barons. London: Pluto Press.

Burrough, B. \& J. Helyar. 2004. Barbarians at the Gate. Lancashire: Arrow.

Callon, M. 1998. 'Introduction.' In M. Callon (Ed.) The Laws of the Markets: 1-57. Oxford: Blackwell.

Callon, M. 2007. 'What does it mean to say that economics is performative.' In D. MacKenzie, F. Muniesa \& L. Siu (Eds.), Do Economists Make Markets? On the Performativity of Economics: 311-57. Princeton: Princeton University Press.

Carroll, A. B. 1987. 'In search of the moral manager.' Business Horizons, 30:2, 7-15.

Chandler, A. D. \& B. Mazlish. 2005. 'Introduction.' In A. D. Chandler \& B. Mazlish (Eds.), Leviathans. Multinational Corporations and the New Global History: 1-15. Cambridge: Cambridge University Press.

Chewning, R. C. 1984. 'Can free enterprise survive ethical schizophrenia.' Business Horizons, $27: 2,5-11$.

Cohan, W. D. 2009. 'A tsunami of excuses.' The New York Times: A29, [online at http://www.nytimes.com/2009/03/12/opinion/12cohan.html].

Cohen, R. \& P. Kennedy. 2000. Global Sociology. London: MacMillan.

Cova, B. \& V. Cova. 2002. 'Tribal marketing: The tribalisation of society and its impact on the conduct of marketing.' European Journal of Marketing, 36, 595-620.

Cutler, A. C. 2001. 'Critical reflections on the Westphalian assumptions of international law and organization: A crisis of legitimacy.' Review of International Studies, 27:2, 133-50.

Davis, J. H. 1997. 'Toward a stewardship theory of management.' Academy of Management Review, 22:1, 20-47.

Den Hond, F. \& F. G. A. De Bakker. 2007. 'Ideologically motivated activism: How activist groups influence corporate social change activities.' Academy of Management Review, 32:3, 901-24.

Di Lorenzo, V. 2007. 'Business ethics: Law as a determinant of business conduct.' Journal of Business Ethics, 71:3, 275-99.

DiMaggio, P. \& W. W. Powell. 1983. 'The iron cage revisited: Institutional isomorphism and collective rationality in organizational fields.' American Sociological Review, 48:2, 147 60 . 
Doh, J. P. \& T. R. Guay. 2006. 'Corporate social responsibility, public policy, and NGO activism in Europe and the United States: An institutional-stakeholder perspective.' Journal of Management Studies, 43:1, 47-73.

Donaldson, L. \& T. W. Dunfee. 1994. 'Toward a unified conception of business ethics: Integrative social contracts theory.' Academy of Management Review, 19:2, 252-84.

Donaldson, T. 1996. 'Values in tension: Ethics away from home.' Harvard Business Review, $74,48-62$.

Elias, N. 1994 [1939]. The Civilizing Process. Oxford: Blackwell.

Elkington, J. 1998. Cannibals with Forks. The Triple Bottom Line of 21st Century Business. Gabriola Island: New Society.

Elster, J. 2009. 'Excessive ambitions.' Capitalism and Society, 4:2, 1-30.

Erickson, R. J. 1995. 'The importance of authenticity for self and society.' Symbolic Interaction, 18:2, 121-44.

Etzioni, A. 1989. 'Toward deontological social sciences.' Philosophy of the Social Science, 19:2, 145-56.

Falk, R. 2002. 'Revisiting Westphalia, discovering post-Westphalia.' The Journal of Ethics, 6:4, 311-52.

Fehr, E. \& S. Gächter. 2002. 'Altruistic punishment in humans.' Nature, 415:6868, 137-40.

Feldman, S. P. 1996. 'The ethics of shifting ties: Management theory and the breakdown of culture in modernity.' Journal of Management Studies, 33:3, 283-99.

Ferraro, F., J. Pfeffer \& R. I. Sutton. 2005. 'Economics language and assumptions: How theories can become self-fulfilling.' Academy of Management Review, 30:1, 8-24.

Fontrodona, J. \& A. J. G. Sison. 2006. 'The nature of the firm, agency theory and shareholder theory: A critique from philosophical anthropology.' Journal of Business Ethics, 66:1, $33-42$.

Frank, R. H., T. Gilovitch \& D. T. Regan. 1993. 'Does studying economics inhibit cooperation?' Journal of Economic Perspectives, 7:2, 159-71.

Frederick, R. E. \& W. M. Hoffman. 1995. 'Environmental risk problems and the language of ethics.' Business Ethics Quarterly, 5:4, 699-711.

Freeman, R. E. 1994. 'The politics of stakeholder theory: Some future directions.' Business Ethics Quarterly, 4:4, 409-21.

Frey, B. S. \& A. Stutzer. 2002. Happiness and Economics. How the Economy and Institutions Affect Well-Being. Princeton, NJ: Princeton University Press.

Friedman, M. 1953. 'The methodology of positive economics.' In M. Friedman (Ed.) Essays in Positive Economics: 3-43. Chicago: University of Chicago Press.

Friedman, M. 2002 [1970]. 'The social responsibility of business is to increase its profits (First published in the New York Times Magazine).' In L. P. Hartman (Ed.) Perspectives in Business Ethics: 225-30. Boston: McGraw Hill.

Galaskiewicz, J. 1991. 'Making corporate actors accountable: Institution-building in Minneapolis-St.Paul.' In W. W. Powell \& P. DiMaggio (Eds.), The New Institutionalism in Organizational Analysis: 293-311. Chicago: University of Chicago Press.

Gergen, K. J. 2000. The Saturated Self. Dilemmas of Identity in Contemporary Life. New York: Basic Books. 
Ghoshal, S. 2005. 'Bad management theories are destroying good management practices.' Academy of Management Learning \& Education, 4:1, 75-91.

Ghoshal, S. \& P. Moran. 1996. 'Bad for practice: A critique of the transaction cost theory.' Academy of Management Review, 21:1, 13-47.

Giddens, A. 1991. Modernity and Self-Identity. Self and Society in the Late Modern Age. Cambridge: Polity Press.

Giddens, A. 1994. 'Living in a Post-Traditional Society.' In U. Beck, A. Giddens \& S. Lash (Eds.), Reflexive Modernization. Politics, Tradition and Aesthetics in the Modern Social Order: 56-109. Cambridge: Polity Press.

Gilovitch, T., D. Griffin \& K. Kahneman. 2002. 'Heuristics and Biases: The Psychology of Intuitive Judgment.' Cambridge: Cambridge University Press.

Giovanola, B. 2009. 'Re-thinking the anthropological and ethical foundation of economics and business: Human richness and capabilities enhancement.' Journal of Business Ethics, 88:3, 431-44.

Gond, J.-P., G. Palazzo \& K. Basu. 2009. 'Reconsidering instrumental corporate social responsibility through the mafia metaphor.' Business Ethics Quarterly, 19:1, 57-85.

Gonin, M. 2007a. 'It is Better to Change the Context than the Individual: Kohlberg's Teaching for Economic Morality.' In B. Wempe \& J. M. Logsdon (Eds.), Proceedings of the 18th Annual Conference of the International Association for Business and Society: 33-38. Florence: International Association for Business and Society.

Gonin, M. 2007b. 'Business research, self-fulfilling prophecy, and the inherent responsibility of scholars.' Journal of Academic Ethics, 5:1, 33-58.

Granovetter, M. 1985. 'Economic action and social structure: The problem of embeddedness.' The American Journal of Sociology, 91:3, 481-510.

Guillebaud, J.-C. 2004. 'Une société en panne d'avenir?' Eglise catholique des HautesPyrénées, [accessed online 2007-03-06 at http://tarbesetlourdes.cef.fr/spip/IMG/ pdf/Guillebaud_04.pdf]

Habermas, J. 1996. Between Facts and Norms. Contributions to a Discourse Theory of Law and Democracy. Cambridge: MIT Press.

Heath, J. 2009. 'The uses and abuses of agency theory.' Business Ethics Quarterly, 19:4, 497528.

Herrnstein, R. J. 1993. 'Behavior, reinforcement, and utility.' In M. Hechter, L. Nadel \& R. E. Michod (Eds.), The Origin of Values: 137-52. New York: Aldine De Gruyter.

Hertwig, R. \& S. M. Herzog. 2009. 'Fast and frugal heuristics: Tools of social rationality.' Social Cognition, 27:5, 661-98.

Hogg, M. A. \& D. J. Terry. 2000. 'Social identity and self-categorization processes in organizational contexts.' Academy of Management Review, 25:1, 121-40.

Hogg, M. A. \& D. J. Terry. 2001. 'Social identity theory and organizational processes.' In M. A. Hogg \& D. J. Terry (Eds.), Social Identity Processes in Organizational Contexts: 112. Hove: Psychology Press.

Hogg, M. A., D. J. Terry \& K. M. White. 1995. 'A tale of two theories: A critical comparison of identity theory with social identity theory.' Social Psychology Quarterly, 58:4, 25569. 
Homans, G. C. 1958. 'Social behavior as exchange.' American Journal of Sociology, 63:6, 597-606.

Jensen, M. C. 2002. 'Value maximization, stakeholder theory, and the corporate objective function.' Business Ethics Quarterly, 12:2, 235-56.

Jensen, M. C. \& W. H. Meckling. 1976. 'Theory of the firm: Managerial behavior, agency costs and ownership structure.' Journal of Financial Economics, 3:4, 305-60.

Jones, T. M. 1995. 'Instrumental stakeholder theory: A synthesis of ethics and economics.' Academy of Management Review, 20:2, 404-37.

Kahneman, D., P. Slovic \& A. Tversky. 1982. 'Judgment under Uncertainty: Heuristics and Biases.' New York: Cambridge University Press.

Khurana, R. 2007. From Higher Aims to Hired Hands. The Social Transformation of American Business Schools and the Unfulfilled Promise of Management as a Profession. Princeton: Princeton University Press.

Kobrin, S. J. 2001. 'Sovereingty@bay: Globalization, multinational enterprise, and the international political system.' In A. M. Rugman \& T. L. Brewer (Eds.), The Oxford Handbook of International Business: 181-205. Oxford: Oxford University Press.

Kobrin, S. J. 2009. 'Private political authority and public responsibility: Transnational politics, transnational firms and human rights.' Business Ethics Quarterly, 19:3, 349-74.

Kulik, B. W. 2005. 'Agency theory, reasoning and culture at Enron: In search of a solution.' Journal of Business Ethics, 59:4, 347-60.

Laufer, W. S. 2003. 'Social accountability and corporate greenwashing.' Journal of Business Ethics, 43:3, 253-61.

Levine, D. P. 2005. 'The corrupt organization.' Human Relations, 58:6, 723-40.

Luhmann, N. 1982. The Differentiation of Society. New York: Columbia University Press.

Maak, T. \& N. M. Pless. 2006. 'Responsible leadership in a stakeholder society - A relational perspective.' Journal of Business Ethics, 66:1, 99-115.

Manstetten, R. 2000. Das Menschenbild der Ökonomie. Der homo oeconomicus und die Anthropologie von Adam Smith. Freiburg: Verlag Karl Alber.

Margolis, J. D. \& J. Walsh. 2003. 'Misery loves companies: Rethinking social initiatives by business.' Administrative Science Quarterly, 48:2, 268-305.

Marwell, G. \& R. E. Ames. 1981. 'Economists free ride, does anyone else? Experiments on the provision of public goods, IV.' Journal of Public Economics, 15:3, 295-310.

Matten, D. \& A. Crane. 2005. 'Corporate citizenship: Toward an extended theoretical conceptualization.' Academy of Management Review, 30:1, 166-79.

May, C. 2004. 'Cosmopolitan legalism meets 'thin community': Problems in the global governance of intellectual property.' Government and Opposition, 39:3, 393-422.

McCabe, D. L., K. D. Butterfield \& L. K. Trevino. 2006. 'Academic dishonesty in graduate business programs: Prevalence, causes, and proposed action.' Academy of Management Learning \& Education, 5:3, 294-308.

McLean, B. \& P. Elkind. 2003. The Smartest Guys in the Room: The Amazing Rise and Scandalous Fall of Enron. New York: Penguin.

Meyer, J. W. \& B. Rowan. 1977. 'Institutionalized organizations: Formal structure as myth and ceremony.' American Journal of Sociology, 83:2, 340-63. 
Mintzberg, H. 2004. Managers Not MBAs. A Hard Look at the Soft Practice of Managing and Management Development. London: Prentice-Hall.

Mintzberg, H., R. Simons \& K. Basu. 2002. 'Beyond selfishness.' Sloan Management Review, 44:1, 67-74.

Moon, J., A. Crane \& D. Matten. 2005. 'Can corporations be citizens? Corporate citizenship as a metaphor for business participation in society.' Business Ethics Quarterly, 15:3, 429-53.

Oliver, C. 1991. 'Strategic responses to institutional processes.' Academy of Management Review, 16:1, 145-79.

Paine, L. S. 1994. 'Managing for organizational integrity.' Harvard Business Review, 72:2, 106-17.

Paine, L. S. 1996. 'Moral thinking in management. An essential capability.' Business Ethics Quarterly, 6:4, 477-92.

Palazzo, G. \& A. G. Scherer. 2006. 'Corporate legitimacy as deliberation: A communicative framework.' Journal of Business Ethics, 66:1, 71-88.

Pareto, V. 1971 [1906]. Manual of Political Economy. New York: Augustus M. Kelley.

Pattberg, P. 2005. 'What role for private rule-making in global environmental governance? Analysing the Forest Stewardship Council (FSC).' International Environmental Agreements, 5, 175-89.

Phillips, K. 2009. 'Senator wants some remorse from C.E.O.'s.' The New York Times: A17, [online at http://www.nytimes.com/2009/03/18/us/politics/18grassley.html?ref=us].

Polanyi, K. 1957. 'Aristotle discovers the economy.' In K. Polanyi, C. M. Arensberg \& H. W. Pearson (Eds.), Trade and Market in the Early Empires. Economies in History and Theory: 64-94. New York: The Free Press.

Popper, K. R. 1990 [1934]. The Logic of Scientific Discovery. Boston: U. Hyman.

Popper, K. R. 2003 [1945]. The Open Society and its Enemies: Volume 2: Hegel and Marx. London: Routledge.

Porter, M. E. \& M. R. Kramer. 2006. 'Strategy and society. The link between competitive advantage and corporate social responsibility.' Harvard Business Review, 84:12, 78-92.

Pruzan, P. 2001. 'The question of organizational consciousness: Can organizations have values, virtues and visions?' Journal of Business Ethics, 29:3, 271-84.

Rawlinson, P. 2002. 'Capitalists, criminals and oligarchs - Sutherland and the new "robber barons".' Crime, Law \& Social Change, 37:3, 293-307.

Rees, R. 1985a. 'The theory of principal and agent: Part 1.' Bulletin of Economic Research, 37:1, 3-26.

Rees, R. 1985b. 'The theory of principal and agent: Part 2.' Bulletin of Economic Research, 37:2, 75-95.

Rest, J. R. 1983. 'Morality.' In P. H. Mussen, J. H. Flavell \& E. M. Markman (Eds.), Handbook of Child Psychology. Volume III: Cognitive Development: 556-629. New York: Wiley.

Sassower, R. 2010. 'Is Homo economics extinct?' Philosophy of the Social Science, 40:4, 60315. 
Scherer, A. G. \& G. Palazzo. 2007. 'Toward a political conception of corporate responsibility. Business and society seen from a Habermasian perspective.' Academy of Management Review, 32:4, 1096-120.

Scherer, A. G., G. Palazzo \& D. Baumann. 2006. 'Global rules and private actors - towards a new role of the TNC in the global governance.' Business Ethics Quarterly, 16:4, 505-32.

Scholte, J. A. 2005. 'Civil society and democratically accountable global governance.' In D. Held \& M. Koenig-Archibugi (Eds.), Global Governance and Public Accountability: 87-109. Oxford: Blackwell.

Selten, R. \& A. Ockenfels. 1998. 'An experimental solidarity game.' Journal of Economic Behavior \& Organization, 34:4, 517-39.

Sennett, R. 1998. Corrosion of Character - The Personal Consequences of Work in the New Capitalism. New York: Norton.

Sethi, S. P. 1975. 'Dimensions of corporate social performance: An analytical framework.' California Management Review, 17:3, 58-64.

Shamir, R. 2004. 'Between self-regulation and the Alien Tort Claims Act: On the contested concept of corporate social responsibility.' Law \& Society Review, 38:4, 635-64.

Shields, S. 2007. 'Too much shock, not enough therapy: Transnational capital and the social implications of Poland's ongoing transition to a market.' Competition \& Change, 11:2, 155-78.

Smith, A. 1981 [1776]. An Inquiry into the Nature and Causes of the Wealth of Nations, Volume 1. Indianapolis: Liberty Fund.

Smith, W. 2007. 'Cosmopolitan citizenship: Virtue, irony and worldliness.' European Journal of Social Theory, 10:1, 37-52.

Solomon, R. C. 1993. Ethics and Excellence. Cooperation and Integrity in Business. Oxford: Oxford University Press.

Stevens, J. M., H. K. Steensma, D. A. Harrison \& P. L. Cochran. 2005. 'Symbolic or substantive document? The influence of ethics codes on financial executives decisions.' Strategic Management Journal, 26:2, 181-95.

Stryker, S. 1980. Symbolic interactionism: A social structural version. Palo Alto: Benjamin/Cummings.

Suchman, M. C. 1995. 'Managing legitimacy: Strategic and institutional approaches.' Academy of Management Review, 20:3, 571-610.

The Economist. 2006. 'The heat is on. A special report on climate change.' The Economist, 380:8494, S1-S24.

Thornton, P. H. 2002. 'The rise of the corporation in a craft industry: Conflict and conformity in institutional logics.' Academy of Management Journal, 45:1, 81-101.

Tolbert, P. S. \& L. G. Zucker. 1996. 'The institutionalization of institutional theory.' In S. R. Clegg, C. Hardy \& W. R. Nord (Eds.), The Handbook of Organization Studies: 175-89. London: Sage.

Wagner-Tsukamoto, S. 2005. 'An economic approach to business ethics: Moral agency of the firm and the enabling and constraining effects of economic institutions and interactions in a market economy.' Journal of Business Ethics, 60:1, 75-89. 
Weaver, G. R., L. K. Trevino \& P. L. Cochran. 1999. 'Integrated and decoupled corporate social performance: Management commitments, external pressure, and corporate ethics practices.' Academy of Management Journal, 42:5, 539-52.

Weber, J. 1991. 'Adapting Kohlberg to enhance the assessment of managers' moral reasoning.' Business Ethics Quarterly, 1:3, 293-318.

Weber, M. 1976 [1906]. Max Weber: Essays in Sociology 302. Oxford: Oxford University Press.

Welzer, H. 2008. Klimakriege. Wofür im 21. Jahrhundert getötet wird. Frankfurt am Main: Fischer.

Wieland, J. 2005. 'Corporate Governance, ValuesManagement and Standards. The European Perspective.' Business and Society, 44:1, 74-93.

Williamson, O. E. 1975. Markets and Hierarchies: Analysis and Antitrust Organization. New York: The Free Press.

Young, I. M. 2004. 'Responsibility and global labor justice.' The Journal of Political Philosophy, 12:4, 365-88.

Zucker, L. G. 1987. 'Institutional theories of organization.' Annual Review of Sociology, 13, 443-64. 